$\xi=-1$

\title{
Organizational Culture and Ethics in Decision-Making
}

\author{
Bibiana Anak Manggai *1, Kassim bin Thukiman ${ }^{2}$, Muhammad Fauzi bin Othman ${ }^{3}$, \\ Muhammad Khairi bin Abdul Majid ${ }^{4}$ \\ ${ }^{1}$ Faculty of Management, Universiti Teknologi Malaysia, 81310 Skudai, Malaysia \\ ${ }^{2}$ Faculty of Management, Universiti Teknologi Malaysia, 81310 Skudai, Malaysia \\ ${ }^{3}$ Faculty of Management, Universiti Teknologi Malaysia, 81310 Skudai, Malaysia \\ ${ }^{4}$ Faculty of Management, Universiti Teknologi Malaysia, 81310 Skudai, Malaysia
}

\begin{abstract}
Malaysia was recorded outnumber of accidents in the world. The traffic Police is the responsible body for ensuring to maintain the law on the road which assists the public for smooth travelling The media reports stated that the traffic police uses their power in wrong ways and is showing not profession with their duties. This happens due to lack of organizational culture among civil servants which are not practiced in the right ways according to the justice and their professions. Therefore, this article focuses on the organizational culture that should be practiced and the decisions that need to be practiced. Further, the ethical factors based decisions should be performed by traffic police. The topic selected will expect to improve the organizational culture and an ethical decision making among law's practitioner and traffic police. In addition, the positive view can also give to the public on the ethical decision making that could be practiced by traffic police. In conclusion, the improvement of organizational culture should be refined to produce law practitioners and implementers in ethical especially for civil servants in decision-making.
\end{abstract}

Keywords: : Organizational Culture; Practice and Cultural Organization; Decision Making, Ethical Decision; Ethical Decision Making Factors

\section{Introduction}

Media Malaysia reported that Malaysia has the highest number of accidents record. The road accidents in 2014 were 476,196 while 489,606 accidents were noticed in 2015 (Department of Statistics Malaysia 2016). Thus, the traffic police has the responsibility for ensuring the road safety for public according to law. The police institution is responsible to protect and maintain the national security by implementing law (Arifin \& Ahmad, 2017).

It is maybe because of the increased cases of misuse of power among law practitioners and implementer including traffic police according the media and the press reported. This cause reduces the worth of traffic police in the sight of public by not profession. According to the Public Complaints Bureau (PCB), most of the complaints received against civil servants as slow services rendered, unfair in their actions or decisions, abuse of power, unethical and failed to implement the rule (Public Complaints Bureau, 2014).

Due to these issues, this article classifies the complaints agains the government servants by public which have been presented in yearly that are 18 complaints received in 2011,357 complaints registered in 2012, 306 complaints registered in 2013, and 312 complaints registered in 2014 (Department of Statistics Malaysia 2016), as depicted in Figure 1. This was supported by the Malaysian Anti-Corruption Commission by showing increased offenses and involved officers and members of the Royal Malaysian Police (PDRM) between 2012 (155 arrests) to 2016 (182 arrests). These offenses were of corruption, position abuse, making false claim and other offenses (Public Complaints Bureau, 2014) (see Table 2).

The causes of this problem is the organizational culture among civil servants which have not been practiced in the right place that effect failure to make ethical decisions in their profession. This article is focus on the topic produced the organizational culture that should be practiced, the kind of decisions to be practiced and factors that making ethical decisions by civil servants, especially the police traffic.

Table1: Number of Officials Misconduct Complaints
\begin{tabular}{|l|l|l|l|l|l|}
\hline Government Agencies & $\mathbf{2 0 1 1}$ & $\mathbf{2 0 1 2}$ & $\mathbf{2 0 1 3}$ & $\mathbf{2 0 1 4}$ & Total \\
\hline $\begin{array}{l}\text { National Anti-Drug } \\
\text { Agency }\end{array}$ & 0 & 1 & 1 & 1 & 3 \\
\hline $\begin{array}{l}\text { Malaysian Maritime } \\
\text { Enforcement Agency }\end{array}$ & 0 & 2 & 3 & 0 & 5 \\
\hline $\begin{array}{l}\text { Malaysian Volunteer } \\
\text { Corps }\end{array}$ & 0 & 1 & 0 & 1 & 2 \\
\hline $\begin{array}{l}\text { Environmental Depart- } \\
\text { ment }\end{array}$ & 0 & 1 & 1 & 2 & 4 \\
\hline $\begin{array}{l}\text { Immigration Depart- } \\
\text { ment of Malaysia }\end{array}$ & 0 & 17 & 15 & 16 & 48 \\
\hline $\begin{array}{l}\text { Royal Malaysian Cus- } \\
\text { toms Department }\end{array}$ & 0 & 7 & 3 & 10 & 20 \\
\hline $\begin{array}{l}\text { Department Occupa- } \\
\text { tional Safety and Em- } \\
\text { ployee Health }\end{array}$ & 0 & 1 & 0 & 0 & 1 \\
\hline $\begin{array}{l}\text { National Registration } \\
\text { Department }\end{array}$ & 0 & 4 & 1 & 3 & 8 \\
\hline & & & & & \\
\hline $\begin{array}{l}\text { Department of Civil } \\
\text { Aviation }\end{array}$ & 0 & 0 & 0 & 0 & 0 \\
\hline Road Transport De- & 0 & 12 & 10 & 11 & 33 \\
\hline
\end{tabular}




\begin{tabular}{|c|c|c|c|c|c|c|}
\hline \multicolumn{7}{|c|}{ partment } \\
\hline \multicolumn{2}{|c|}{$\begin{array}{l}\text { Industrial Relation de- } \\
\text { partment }\end{array}$} & 0 & 0 & 1 & 2 & 3 \\
\hline \multicolumn{2}{|c|}{ department of Fisheries } & 0 & 0 & 1 & 1 & 2 \\
\hline \multicolumn{2}{|c|}{$\begin{array}{l}\text { Department of Wild fare } \\
\text { and National Parks }\end{array}$} & 0 & 0 & 0 & 0 & 0 \\
\hline \multicolumn{2}{|c|}{ Department of Labor } & 0 & 0 & 3 & 1 & 4 \\
\hline \multicolumn{2}{|c|}{ Department of Health } & 0 & 3 & 3 & 1 & 7 \\
\hline \multicolumn{2}{|c|}{$\begin{array}{l}\text { Ministry of Tourism and } \\
\text { Culture Malaysia }\end{array}$} & 0 & 0 & 1 & 0 & 1 \\
\hline \multicolumn{2}{|c|}{$\begin{array}{l}\text { Ministry of Domestic } \\
\text { Trade, Co-Operatives } \\
\text { and Consumerism }\end{array}$} & 0 & 2 & 4 & 4 & 10 \\
\hline \multicolumn{2}{|c|}{$\begin{array}{l}\text { Ministry of Urban Well- } \\
\text { being, Housing and Lo- } \\
\text { cal Government }\end{array}$} & 0 & 9 & 2 & 2 & 13 \\
\hline \multicolumn{2}{|c|}{ Royal Malaysia Police } & 17 & 253 & 215 & 222 & 707 \\
\hline \multicolumn{2}{|c|}{ Others Agencies } & 1 & 44 & 42 & 35 & 122 \\
\hline \multicolumn{2}{|c|}{ Total } & 18 & 357 & 306 & 312 & 993 \\
\hline \multicolumn{7}{|c|}{ Source: SIAP Report (2014) } \\
\hline Bill & Offenses & 2012 & 2013 & 2014 & 2015 & 2016 \\
\hline 1 & $\begin{array}{l}\text { Receive } \\
\text { corruption }\end{array}$ & 140 & 48 & 111 & 153 & 171 \\
\hline 2 & $\begin{array}{l}\text { Abuse of } \\
\text { Position }\end{array}$ & 0 & 0 & 0 & 1 & 0 \\
\hline 3 & $\begin{array}{l}\text { False } \\
\text { claims }\end{array}$ & 15 & 3 & 0 & 8 & 8 \\
\hline 4 & $\begin{array}{l}\text { Others } \\
\text { Offenses }\end{array}$ & 0 & 5 & 0 & 0 & 3 \\
\hline Total & & 155 & 56 & 111 & 162 & 182 \\
\hline
\end{tabular}

Source: Anti-Corruption Commission (2016)

\section{Literature Review}

The selection of this topic has been carried out due to versatile number of variables avaialble which will suppot us for making decisions. This topic was chosen because researcher need to find out the organizational culture which should be practiced, kind of ethical decisions and ethical decision-making factor in an organization. The ethical behavior is the rule, the people customs and assertion of a right and bad (Johnson, 1992). However, the organizational culture and ethical decisions of an organization are interlinked (Winstanley \& Woodall, 2000). Besides that, the organizational culture can increase productivity and organizational image which can be generated by ethical considerations (Cameron \& Quinn, 2011).

\subsection{Organizational Culture to be Practiced}

The practice and perception of all employees in the organization should be based on the values of organizational culture (Hogan \& Coote, 2014). It has been observed that the organization productivity are grow up towards achievement of goals when they are satisfay from their responsibiltites (Mathisen \& Einarsen, 2004) Megat Ayop.

This is good for emulate organizational culture by making a guide or manual in the work process (Alvesson \& Sveningsson, 2015). The aim of the organization is to create culture of discipline that forms intregiti and produces an acceptable and practiciable by all members of the organization which can facilitate work of management and administration (Denison, Nieminen, \& Kotrba, 2014). When an organization has values, beliefs and expectations that can be shared among the members, as stated in (Armstrong, 2011).

In the same time the organization requires norms and attitudes which assists to re-shape the behavior as compared to respect and trust to avoid conflict by not harming fellow members (Hofstede, 2011). It has five factors to determine the organizational culture including power and distance; individualism and kolektitivisme; masculinity and femininity; avoid and uncertainties with short and long term (Huang, Yang, Wu, Shi, \& Amirteimoori, 2017). These five factors are used as a model for assessment of the organizational culture and country. The finding from using Hofstede (2011) model found that the organizational culture has a balanced relationship to the achievement of an organization (Yiing \& Ahmad, 2009).

To get balanced organizational culture, there are six methods which should be practiced in an organization including respectful; mutual sharing of information; open to changes in the organizational structure; ready to answer customer questions; participate in the organization to facilitate the decision making process; and always respecting the environment (Yiing \& Ahmad, 2009). The method described can be applied in an organization such as top management, restructuring and organizational culture. It is very important to facilitate the organization achievements and their goals.

\subsection{Types of Ethical Decisions}

Good or bad organization can be determined by types of decisionmaking (Ford \& Richardson, 2013). This matter is importance for making ethical decisions in stages for organization. Through the ethical practices concept, it can bring some effect likes coinciding, conscientious, empowerment and employability (Brockett \& Hiemstra, 2005). However, the ethical decision-making can run in three division likes the value system, various selection and operations value that can form a code of ethics. The value system part was created by various types of questions inlcuding what and how where they belief on various selection of responsibilities which are based on number of students, employers, professionals and community. From this identified values, it will create a code of ethics to facilitate and implement unofficially.

The ethical decision can be classified into four level including majority, hierarchy, proportionately and consensus (Matić \& Bulog, 2012). The majority can produce consensus by voting which is based on issues. The heirarchy decision are made and based on the accumulation of ideas between tops and bottoms employer for making decision which have been come from top management. The proportionately decision involves certain issues and top employees, while the decision involves a small unit where everyone consenses to resolve problem.

In other ways, the ethical decisions can conduct in naturally and strategically (Ferrell \& Fraedrich, 2015). The naturally desicion results that conductes in nature by involving long-term structured strategic plan, complex and risky. The strategy decison is performed with analytical approach which produces proactive and comprehensive results by using methodology. Where the intuitive approach that can indicate the level of knowledge, experience and information which has been obtained unofficially.

\subsection{Ethical Decision-Making Factors}

The ethical decision is an importan for making decision in the organization (Treviño, Weaver, \& Reynolds, 2006). This factor can get from the workers who have high moral and able to make ethical decision (Devettere, 2009), which have obatined experience in various stages. The statement is same with previous studies that also found that top employees is an employee who can manage time, resources and authority to achieve organizational goals and interests of all parties Devettere (2009). 
This can be seen through their maturity in selecting multi tasking employees which are capable to select manpower (Chu, Kamal, \& Kim, 2013). Besides that the other factor for the top officer criteria is that they have individualism and high collectivism charecters for efficiently organizing time (Certo, Lester, Dalton, \& Dalton, 2006; Rapp, Beitelspacher, Grewal, \& Hughes, 2013; Shields, Bonner, \& Moons, 2015). In addition, the value system, selection and priority are factors to produce ethical decisions (Haider 2016). In other way, we also can make combination of exatly information and reliable to produce good results in ethic.

The theoretical and descriptive normative principles; theory and organizational structure; chain of command; the system structure; environment analysis; the level of interest (formalization); and factors beyond reach can be used in desicion ethic for program managers (Haidar, 2016). In addition, the ethical decision-making process can makecriteria, collect various types of information according to the quality differentiation (Vuorinen, 2015). The recognition of issues are need to use as guideliens for making efficient decision. It is similar to the model (Vuorinen, 2015).

\section{Methodology}

This study aims to examine variables which will assist to use for future study. The topic is the organization culture that need to be practiced, types of ethical decisions and ethical decision-making factor in an organization. The researcher should search out the topic with keywords include "organizational culture", "type of ethical decision", "the ethical decision-making" and "ethical decisions" through Google Scholar, JSTOR, Digital Library and Emerald Insight. As result of these searches, only 31 values have been selected as true and right about variables.

\section{Findings and Discussion}

From our reading through related articles in this study it was found that organizational culture can greatly affect results which will be decided by someone in the organization. This is because every decision will involve a number of processes in small units and it will bring to the highest for producing a set of guidelines for specific problem that comes in management, procedures and so on. The process should be referring from the type and levels to produce ethical and fair result to all parties. Besides that, working experience in an organization is very important to produce more ethical decision than the ability to identify the type of work and scope in unit and the labor's requirements.

\section{Conclusion}

The updated organizational culture is important that implements laws such as traffic police. It has been noticed from existing studies that factors affects the cultural values of organization in making decision. It is because the organizational culture practice can reflect the character of the worker and the decisions will take when an issue rose. Through the organization's culture, types of ethical decisions and decision-making factors from the readings that have been carried out to provide guidance to organizations, especially to the traffic police. This is to refine and improve the organizational culture of traffic police for reducing misconduct with civil servants which can change our today's society from negative perspective.

\section{References}

[1] Alvesson, M., \& Sveningsson, S. (2015). Changing organizational culture: Cultural change work in progress: Routledge.
[2] Arifin, M. A. M., \& Ahmad, A. H. (2017). Kepentingan budaya integriti dan etika kerja dalam organisasi di Malaysia: Suatu tinjauan umum. Geografia-Malaysian Journal of Society and Space, 12(9).

[3] Armstrong, M. (2011). Armstrong's handbook of strategic human resource management: Kogan Page Publishers.

[4] Brockett, R. G., \& Hiemstra, R. (2005). Promoting ethical practice in adult education. Adult Learning, 16(3-4), 4-6.

[5] Cameron, K. S., \& Quinn, R. E. (2011). Diagnosing and changing organizational culture: Based on the competing values framework: John Wiley \& Sons.

[6] Certo, S. T., Lester, R. H., Dalton, C. M., \& Dalton, D. R. (2006). Top management teams, strategy and financial performance: A meta-analytic examination. Journal of Management studies, 43(4), 813-839.

[7] Chu, S.-C., Kamal, S., \& Kim, Y. (2013). Understanding consumers' responses toward social media advertising and purchase intention toward luxury products. Journal of Global Fashion Marketing, 4(3), 158174.

[8] Denison, D., Nieminen, L., \& Kotrba, L. (2014). Diagnosing organizational cultures: A conceptual and empirical review of culture effectiveness surveys. European Journal of Work and Organizational Psychology, 23(1), 145-161.

[9] Devettere, R. J. (2009). Practical decision making in health care ethics: Cases and concepts: Georgetown University Press.

[10] Ferrell, O. C., \& Fraedrich, J. (2015). Business ethics: Ethical decision making \& cases: Nelson Education.

[11] Ford, R. C., \& Richardson, W. D. (2013). Ethical decision making: A review of the empirical literature Citation classics from the Journal of Business Ethics (pp. 19-44): Springer.

[12] Haidar, A. D. (2016). Mathematical Methods - Statistics and Forecasting Construction Program Management-Decision Making and Optimization Techniques (pp. 99-129): Springer.

[13] Hofstede, G. (2011). Dimensionalizing cultures: The Hofstede model in context. Online readings in psychology and culture, $2(1), 8$

[14] Hogan, S. J., \& Coote, L. V. (2014). Organizational culture, innovation, and performance: A test of Schein's model. Journal of Business Research, 67(8), 1609-1621.

[15] Huang, Z., Yang, F., Wu, D. D., Shi, V., \& Amirteimoori, A. (2017). Decision-Making Modeling in Service Systems. Mathematical Problems in Engineering, 2017.

[16] Johnson, G. (1992). Managing strategic change — strategy, culture and action. Long Range Planning, 25(1), 28-36.

[17] Mathisen, G. E., \& Einarsen, S. (2004). A review of instruments assessing creative and innovative environments within organizations. Creativity Research Journal, 16(1), 119-140.

[18] Matić, I., \& Bulog, I. (2012). The Nature of Strategic Decision MakingExploiting the Role of Managers' Incremental and Radical Learning. The Journal of International Management Studies, 7(2), 7-19.

[19] Rapp, A., Beitelspacher, L. S., Grewal, D., \& Hughes, D. E. (2013). Understanding social media effects across seller, retailer, and consumer interactions. Journal of the academy of marketing science, 41(5), 547566.

[20] Shields, G. S., Bonner, J. C., \& Moons, W. G. (2015). Does cortisol influence core executive functions? A meta-analysis of acute cortisol administration effects on working memory, inhibition, and set-shifting. Psychoneuroendocrinology, 58, 91-103.

[21] Treviño, L. K., Weaver, G. R., \& Reynolds, S. J. (2006). Behavioral ethics in organizations: A review. Journal of Management, 32(6), 951990.

[22] Vuorinen, J. (2015). Decision Making Models and Tools to Support Strategic Decision Making-Case: Tarvekaluste Oy.

[23] Winstanley, D., \& Woodall, J. (2000). The ethical dimension of human resource management. Human Resource Management Journal, 10(2), 5 20.

[24] Yiing, L. H., \& Ahmad, K. Z. (2009). The moderating effects of organizational culture on the relationships between leadership behaviour and organizational commitment and between organizational commitment and job satisfaction and performance. Leadership \& Organization Development Journal, 30(1), 53-86 